\title{
LAYANAN KESEHATAN DAN PENINGKATAN KETERAMPILAN WIRAUSAHA JAMUR TIRAM KELOMPOK ANAK-ANAK TUNANETRA YPAB SUKOLILO
}

\section{HEALTH SERVICES AND ENHANCEMENT OF OYSTER MUSHROOM ENTERPRENEURSHIP TO THE BLIND CHILDREN YPAB SUKOLILO}

\author{
Pratiwi Soesilawati \\ Departemen Biologi Oral FKG UNAIR, Jl. Prof. Dr. Moestopo No. 47 Surabaya 60132 Indonesia \\ Telp: (+6231) 5030255, email: pratiwi_gunawan@yahoo.com
}

\section{R. Darmawan Setijanto}

Departemen Ilmu Kesehatan Gigi Masyarakat, FKG UNAIR, Jl. Prof. Dr. Moestopo No. 47Surabaya 60132 Indonesia Telp: (+6231) 5030255, email: darmawansetijanto@gmail.com

\begin{abstract}
Abstrak
Hidup sehat seperti yang didefinisikan oleh World Health Organization (WHO) adalah keadaan sejahtera dari badan, jiwa, dan social, sehingga seseorang hidup produktif secara sosial dan ekonomi. Yayasan Pendidikan Anak Buta Surabaya menaungi asrama dan sekolah Taman Kanak-Kanak, SD, SMP dan SMA. Siswa sekolah tunanetra adalah kelompok masyarakat yang masih memerlukan pendampingan kesehatan dan ekonomi. Biaya hidup siswa selama di asrama dan sekolah tunanetra sebagian besar ditopang oleh donatur. Hanya sebagian kecil siswa yang berasal dari keluarga ekonomi menengah dan mampu membayar uang sekolah serta biaya hidup, sehingga beban yayasan untuk menyelenggarakan pendidikan dan biaya hidup sehari-hari sangat berat. Untuk itu Tim Pengabdian Masyarakat Fakultas Kedokteran Gigi Universitas Airlangga merancang kegiatan pendampingan dalam bentuk layanan kesehatan dan pelatihan teknologi tepat guna. Tujuan kegiatan ini adalah meningkatkan derajat kesehatan siswa tunanetra dan mempersiapkan siswa tunanetra menjadi insan yang produktif secara ekonomi melalui pendampingan wirausaha jamur tiram. Target khusus dari kegiatan ini adalah menanamkan kebiasaan hidup bersih sehat kepada siswa dan melatih siswa terlibat dalam produksi dan manajemen pemasaran jamur tiram sebagai teknologi tepat guna untuk bekal hidup di kemudian hari. Solusi yang digunakan adalah layanan kesehatan umum melalui rintisan pembentukan Usaha Kesehatan Sekolah bekerjasama dengan dokter dari pusat pelayanan kesehatan dalam hal ini Rumah Sakit Pendidikan Universitas Airlangga untuk pelayanan kesehatan mata, kesehatan umum, kesehatan anak dan kesehatan gigi. Peningkatan produktifitas ekonomi dilakukan melalui pelatihan wirausaha jamur tiram, praktik pengolahan jamur tiram dan manajemen pemasaran jamur tiram beserta hasil olahannya. Pada akhir kegiatan, siswa memiliki dasar pengetahuan kebersihan dan kesehatan untuk memelihara kesehatan dan memiliki soft skill wirausaha jamur tiram sebagai bekal hidup
\end{abstract}

Kata kunci: jamur tiram, kesehatan gigi, wirausaha, YPAB Sukolilo

\begin{abstract}
Healthy living as defined by the World Health Organization (WHO) is a prosperous state of body, soul, and social, so that one lives productively socially and economically. Yayasan Pendidikan Anak Buta (YPAB) Surabaya houses dormitories and schools of Kindergarten, elementary, junior and senior high schools. Blind school students are community groups that still require health and economic assistance. The cost of living for students in dormitories and schools of the blind is largely sustained by donors. Only a small proportion of students come from middle-income families and are able to pay tuition and living expenses, so the burden of the foundation to provide education and living expenses is very heavy. For that the Community Service Team of Faculty of Dentistry Airlangga University to design assistance activities in the form of health services and appropriate technology training. The purpose of this activity is to improve the health status of blind students and prepare blind students to be economically productive through the accompaniment of oyster mushroom entrepreneur. The specific target of this activity is to instill clean healthy living habits to students and train students involved in the production and marketing management of oyster mushrooms as the appropriate technology for the provision of life in the future. The solution used is public health services through the establishment of School Health Enterprises in collaboration with doctors from health care centers in this case Airlangga University Education Hospital for eye health services, general health, children's health and dental health. Increased economic productivity is done
\end{abstract}


through the training of oyster mushroom entrepreneur, oyster mushroom processing and marketing management of oyster mushroom and its processed products. At the end of the activity, students have basic knowledge of hygiene and health to maintain health and have soft skill entrepreneur of oyster mushroom as stock of life

Keywords: dental health, entrepreneurship, oyter mushroom, YPAB Sukolilo

\section{PENDAHULUAN}

Yayasan Pendidikan Anak Buta (YPAB) Jawa Timur menaungi asrama anak tunanetra dan Sekolah Luar Biasa setingkat SMP dan SMA di Kecamatan Gebang Putih Surabaya serta Sekolah Luar Biasa setingkat Taman KanakKanak dan Sekolah Dasar di Kelurahan Tegal Sari Surabaya. Yayasan Pendidikan Anak Tunanetra (YPAB) didirikan oleh Alm Bp Soetopo, mantan menteri kesehatan RI. Siswasiswa ini melakukan kegiatan belajar, bermain musik dan bersosialisasi di lingkungan asrama. Yayasan di Gebang Putih terletak pada area seluas $10.600 \mathrm{~m} 2$, terdiri dari bangunan asrama dan sekolah, sehingga masih tersedia lahan tidur yang dapat dimanfaatkan oleh siswa untuk belajar berbagai hal, salah satunya pelayanan kesehatan dan wirausaha berbentuk agrobisnis. Pemberdayaan masyarakat yang ditekankan pada kegiatan ini adalah meningkatkan derajat kesehatan gigi dan kesehatan umum melalui pembentukan Usaha Kesehatan Sekolah (UKS) dan ketrampilan siswa tunanetra yang berada dalam naungan Yayasan Pendidikan Anak Buta agar mereka mampu mandiri secara ekonomi melalui transfer Iptek wirausaha jamur tiram. Kegiatan ini meliputi alih iptek pengetahuan dasar kesehatan umum dan gigi, alih iptek metode pembuatan bangunan areal berkebun jamur tiram, alih iptek pengolahan dan pengawetan jamur tiram dan alih iptek pemasaran produk jamur tiram serta pemasaran hasil olahan jamur tiram.

Pembiakan jamur tiram adalah bidang wirausaha yang kami pandang tepat dikembangkan di sekolah tunanetra ini mengingat lokasi pertanian terletak dalam ruang sehingga siswa penyandang tunanetra mudah dan aman untuk melakukan aktifitas bertanam. Mengingat indera peraba dan pendengaran adalah panca indera yang paling peka pada siswa tunanetra, maka bertanam jamur adalah pilihan yang sesuai karena kontrol pertumbuhan jamur dapat dilakukan melalui indera peraba. Jamur tiram dapat tumbuh di daerah dataran rendah dengan cara mengatur kondisi, suhu dan kelembaban ruang pertumbuhan jamur tiram. Nilai gizi jamur tiram cukup tinggi, dimana jamur segar dalam 100 gram di dalamnya terdapat 15 kalori, protein 3,8 gram, lemak 0,6 gr, karbohidrat 0,9 gr, kalsium $3 \mathrm{mg}$, zat besi 1,7 mg, vitamin B 0,1 mg dan vitamin C $5 \mathrm{mg}$. Sedangkan pada 100 gram jamur kering terdapat 128 kalori, protein 16 gram, lemak 0,9 gr, karbohidrat 64,6 mg, kalsium $51 \mathrm{mg}$, zat besi 6,7 mg, dan vitamin B 0,1 mg.

Atas dasar alasan-alasan tersebut diatas timbul pemikiran perlunya dilaksanakan pengabdian masyarakat secara terpadu, melibatkan berbagai disiplin ilmu yaitu ilmu kesehatan serta Sain dan Teknologi. Luaran program ini diharapkan akan menghasilkan anak didik YPAB yang dapat menikmati fasilitas Kesehatan terutama kesehatan mata dan gigi dan siswa mampu mandiri secara ekonomi melalui soft skill wirausaha jamur tiram .

\section{METODE PELAKSANAAN}

Pendekatan yang akan ditawarkan dari kegiatan ini adalah suatu kerjasama, melibatkan seluruh siswa YPAB dan tim pengabdian masyarakat Fakultas Kedokteran Gigi Universitas Airlangga dan RSUD Dr. Soetomo, fakultas Sains dan Teknologi Universitas Airlangga dan Fakultas Teknologi Pangan Universitas Brawijaya. Kegiatan yang dilakukan meliputi: Merancang pendirian UKS di YPAB Gebang Putih dan YPAB Tegal Sari Surabaya bekerjasama dengan dokter mata, dokter anak, dokter gigi dan dokter umum; Pelatihan kebersihan diri dan lingkungan; Pelatihan wirausaha jamur tiram; Pelatihan pengawetan dan pengolahan hasil panen jamur tiram; Pelatihan menejemen pemasaran hasil panen; dan Evaluasi kegiatan.

Pada kegiatan ini partisipasi mitra (siswa tunanetra) berperan aktif dalam semua kegiatan terutama dalam praktek

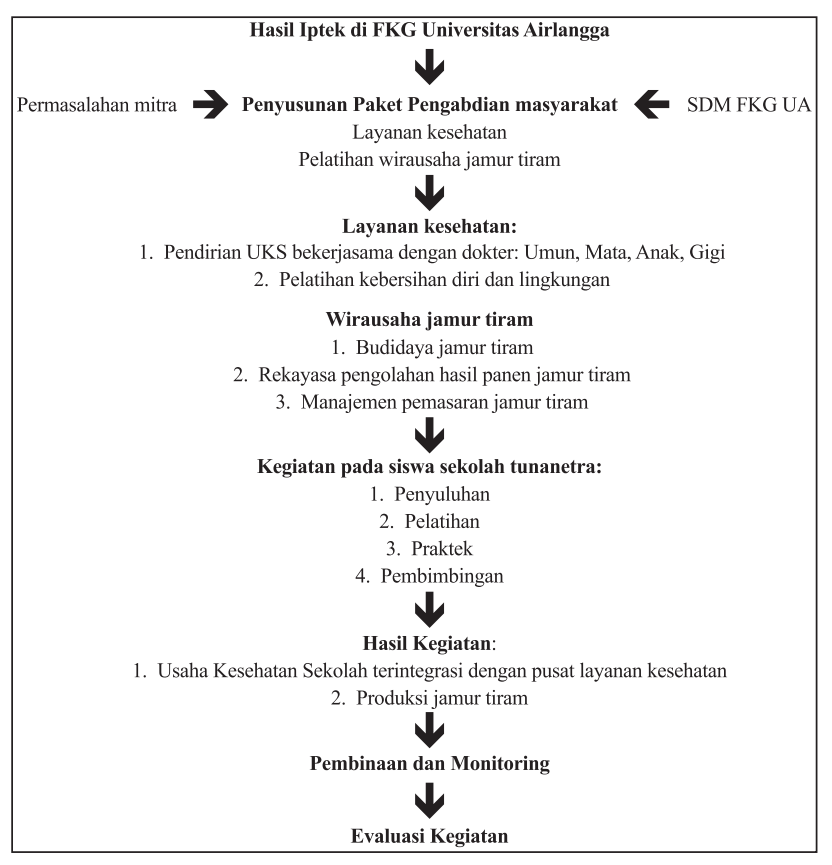

Gambar 1. Pendekatan yang ditawarkan dalam kegiatan Layanan Kesehatan dan peningkatan ketrampilan wirausaha jamur tiram 
wirausaha dan praktek pengolahan hasil panen. Siswa YPAB berjumlah berjumlah 124 siswa, merupakan siswa dari YPAB Gebang Putih (58 siswa) dan Tegal sari (66 siswa) di Surabaya. Diharapkan seluruh siswa memperoleh bekal soft skill dalam wirausaha jamur tiram ini, dan di sisi lain siswa dapat menikmati fasilitas kesehatan secara paripurna. Realisasi metode layanan kesehatan dan peningkatan ketrampilan wirausaha jamur tiram tampak pada gambar 1 .

\section{HASIL DAN PEMBAHASAN}

Pelaksanaan program Iptek bagi Masyarakat telah mulai dilaksanakan sejak Maret 2015 dengan beberapa kegiatan, meliputi:

\section{Aspek Kesehatan}

1. Peningkatan Kesehatan Umum dan Mata Anak-Anak Tunanetra

Kesehatan umum meliputi pemeriksaan kesehatan umum, pengobatan, pemeriksaan kimia klinik darah bagi siswa, orang tua siswa, guru dan karyawan. Kegiatan yang telah dilakukan adalah penyuluhan kesehatan lingkungan dan kebersihan diri sendiri. Pemeriksaan kesehatan mata sangat diperlukan oleh siswa sekolah tunanetra dengan pendampingan dari dokter spesialis mata. Layanan kesehatan umum dan mata telah dilakukan pada tanggal 22 Agustus 2015 di YPAB Tegal Sari mencakup 78 pasien.

Perawatan kesehatan umum dan mata di YPAB Gebang Putih dilaksanakan pada tanggal 29 Agustus 2015. Pada kegiatan telah dilayani 97 pasien terdiri dari siswa, guru, orang tua siswa dan karyawan.

\section{Layanan Kesehatan Gigi}

Kendala mendapatkan layanan kesehatan gigi karena mereka harus meninggalkan lingkungan asrama untuk pemeriksaan dan perawatan kesehatan. Di sisi lain, saat meninggalkan lokasi asrama, mereka harus mendapatkan pengawalan dari guru untuk menjaga keselamatan. Jumlah guru dan pendamping siswa di Yayasan ini sangat terbatas. Sebagai solusi dari masalah ini maka kami merancang kegiatan perawatan gigi di lokasi Yayasan Pendidikan Anak Buta dengan harapan siswa tidak perlu meninggalkan asrama. Kegiatan ini telah dilaksanakan pada tanggal 22 agustus 2015 di YPAB TKLB dan SDLB Tegal Sari Surabaya.

Layanan kesehatan gigi di YPAB Gebang Putih dilaksanakan tanggal 29 Agustus 2015. Layanan ini berhasil melayani 34 pasien. Layanan kesehatan gigi meliputi penyuluhan Dental Health Education dan, screening kesehatan gigi dan intra oral. Perawatan gigi dasar yaitu ekstraksi gigi, tumpatan sederhana, perawatan mumifikasi saluran akar dan scaling.

\section{Usaha Kesehatan Sekolah}

Pendirian UKS yang bekerjasama dengan pusat layanan kesehatan di lingkungan sekolah tunanetra sangat diperlukan untuk memenuhi kebutuhan perawatan kesehatan. Dinas Pendidikan Kota Surabaya mewajibkan tiap sekolah memiliki UKS. Kegiatan yang telah dilaksanakan adalah renovasi ruang yang akan digunakan untuk UKS meliputi pengecatan

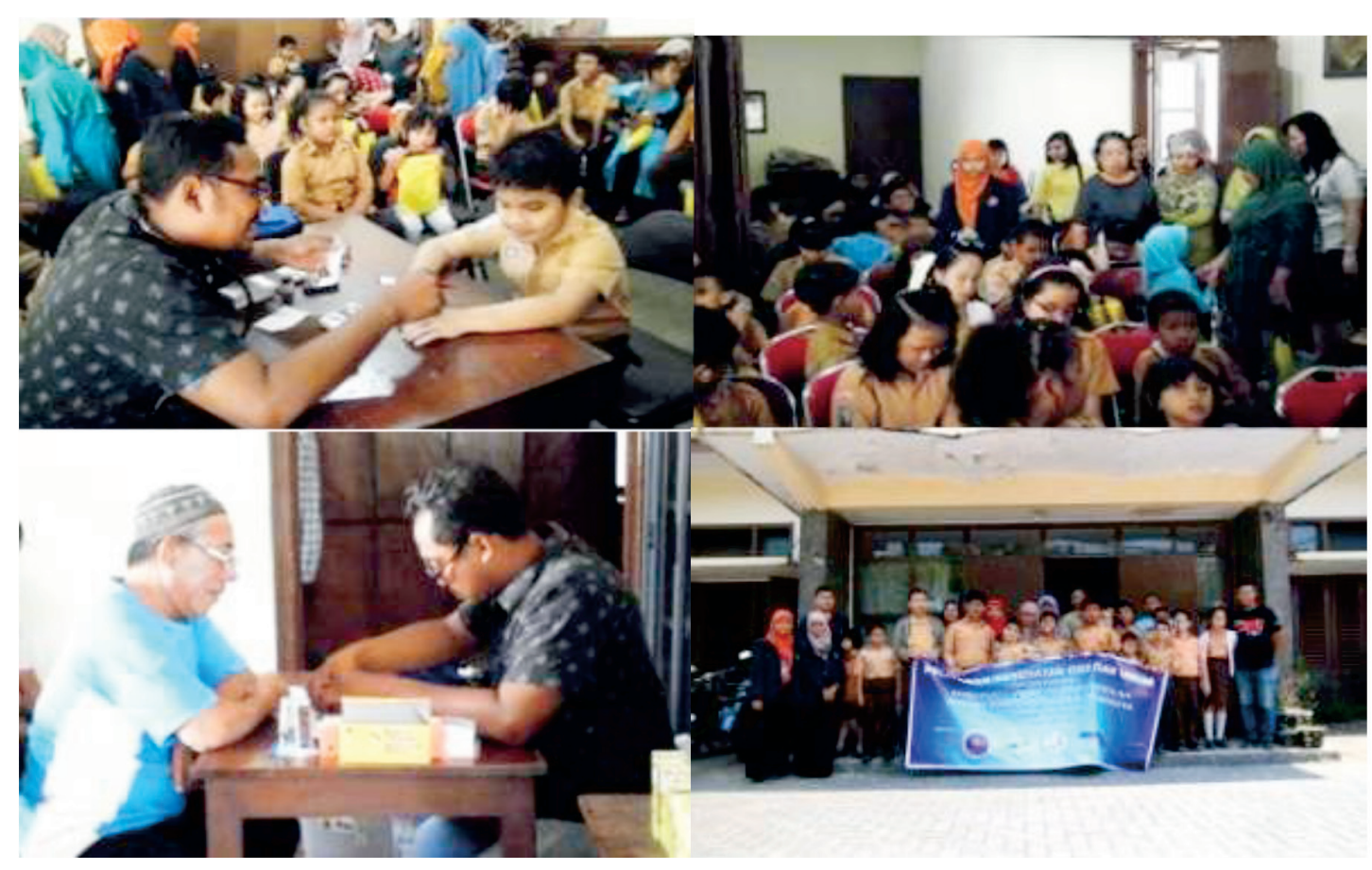

Gambar 2. Pelayanan kesehatan umum di YPAB TKLB dan SDLB Tegal Sari, tanggal 22 Agustus 2015 untuk siswa, orang tua siswa, guru dan karyawam. 


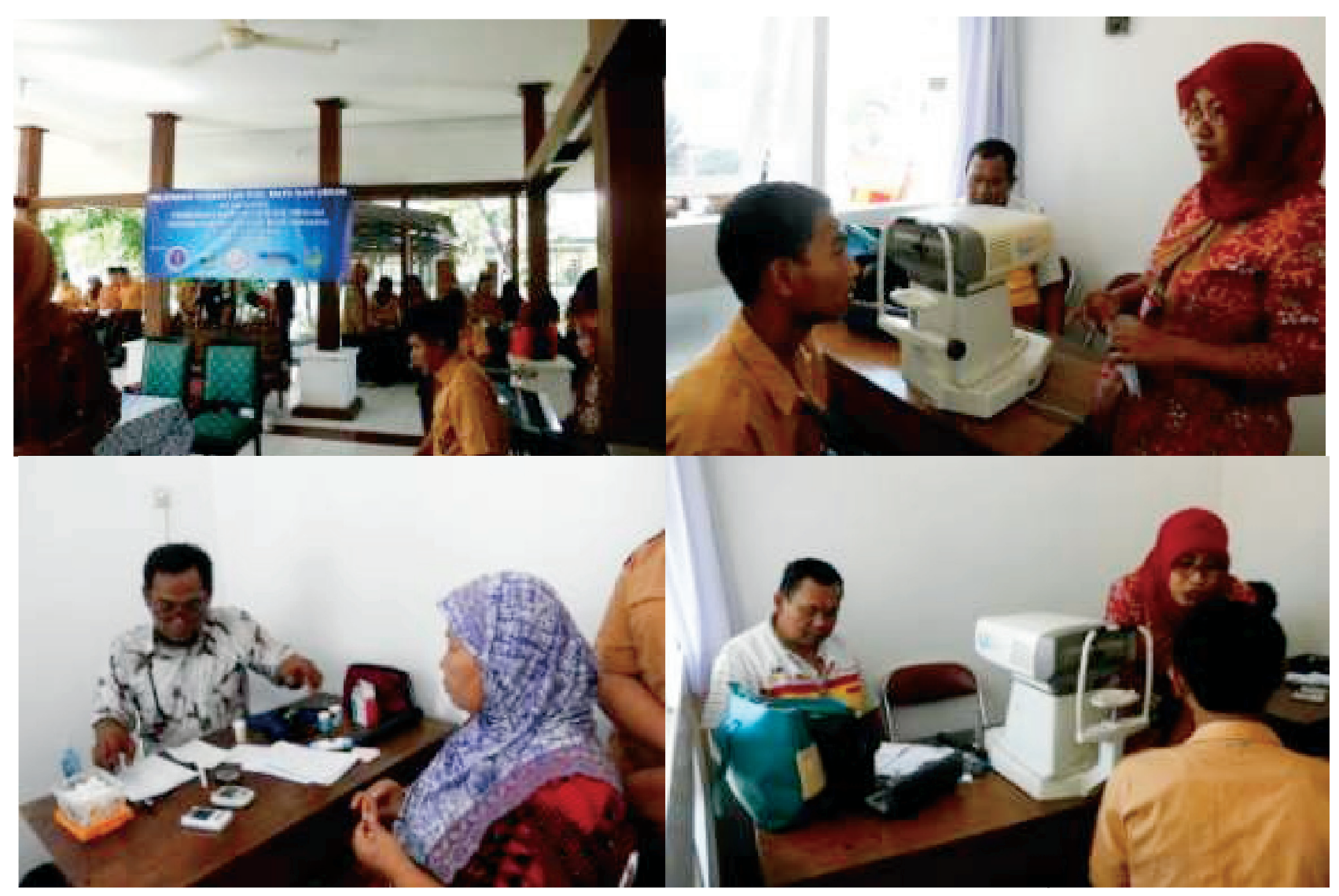

Gambar 3. Pelayanan kesehatan umum, pemeriksaan kimia klinik darah dan pemeriksaan mata di SMPLB dan SMALB YPAB Gebang Putih, tanggal 29 Agustus 2015 untuk siswa, orang tua, guru kan karyawan.

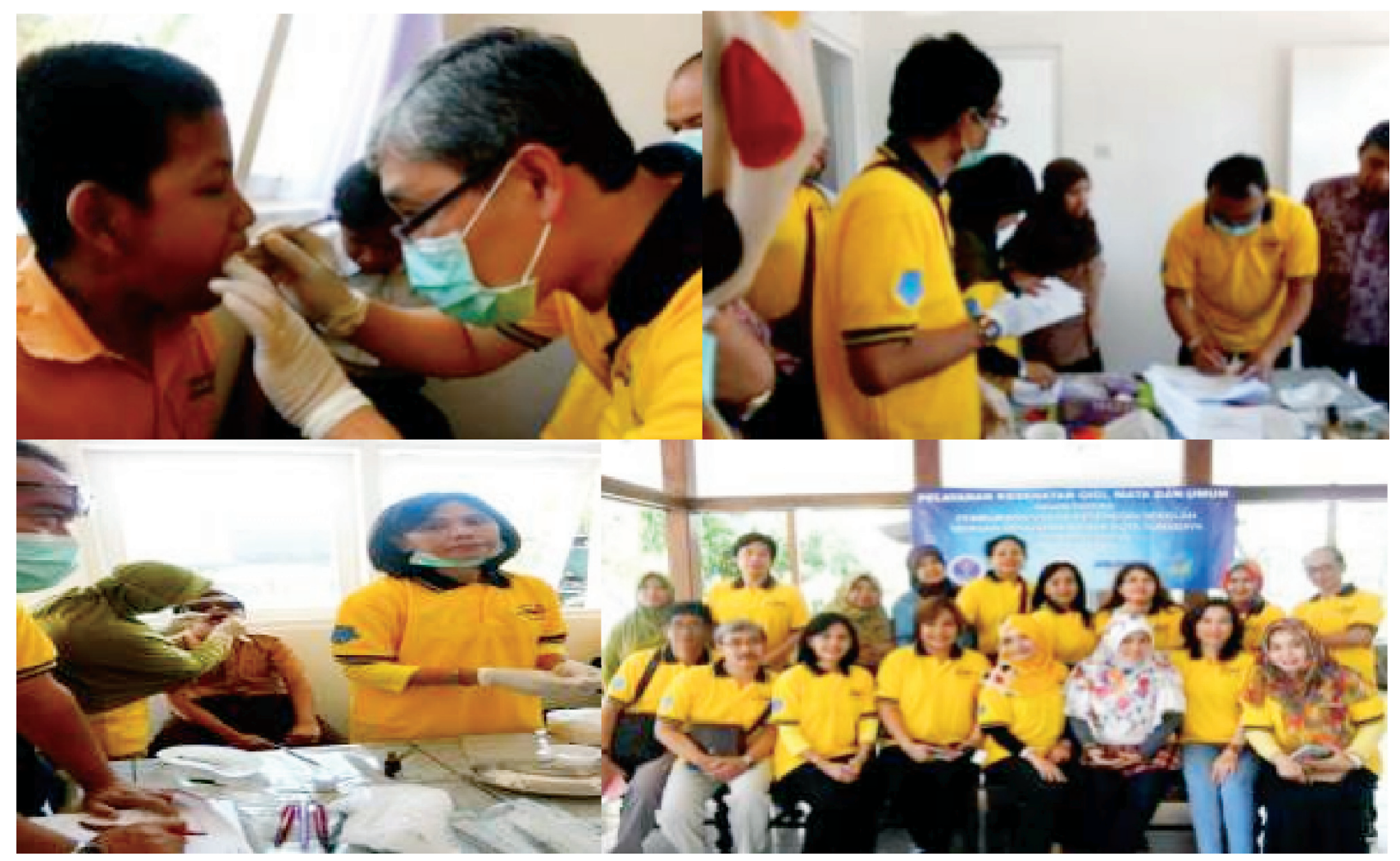

Gambar 4. Pelayanan kesehatan gigi di YPAB Gebang Putih. 
dinding luar dan dalam ruangan, mengganti seluruh pintu, memasang gorden di seluruh ruangan, dan perbaikan atap gedung UKS. Saat ini UKS telah dilengkapi dengan peralatan pemeriksaan kesehatan umum standar yaitu 1 tempat tidur, stetoskop, tensi meter dan obat standar. Ruang ini akan dilengkapi pula dengan hand instrument kedokteran gigi dan obat serta bahan kedokteran gigi untuk perawatan darurat.

\section{Meningkatkan kebersihan diri dan lingkungan anak- anak tunanetra}

Melalui kegiatan UKS, higieni siswa berusaha ditingkatkan melalui penyuluhan dan lomba kebersihan asrama. Penyuluhan dan lomba kebersihan asrama akan dilaksanakan pada tanggal 15 Agustus 2015 sekaligus memperingati perayaan kemerdekaan Republik Indonesia ke 60.

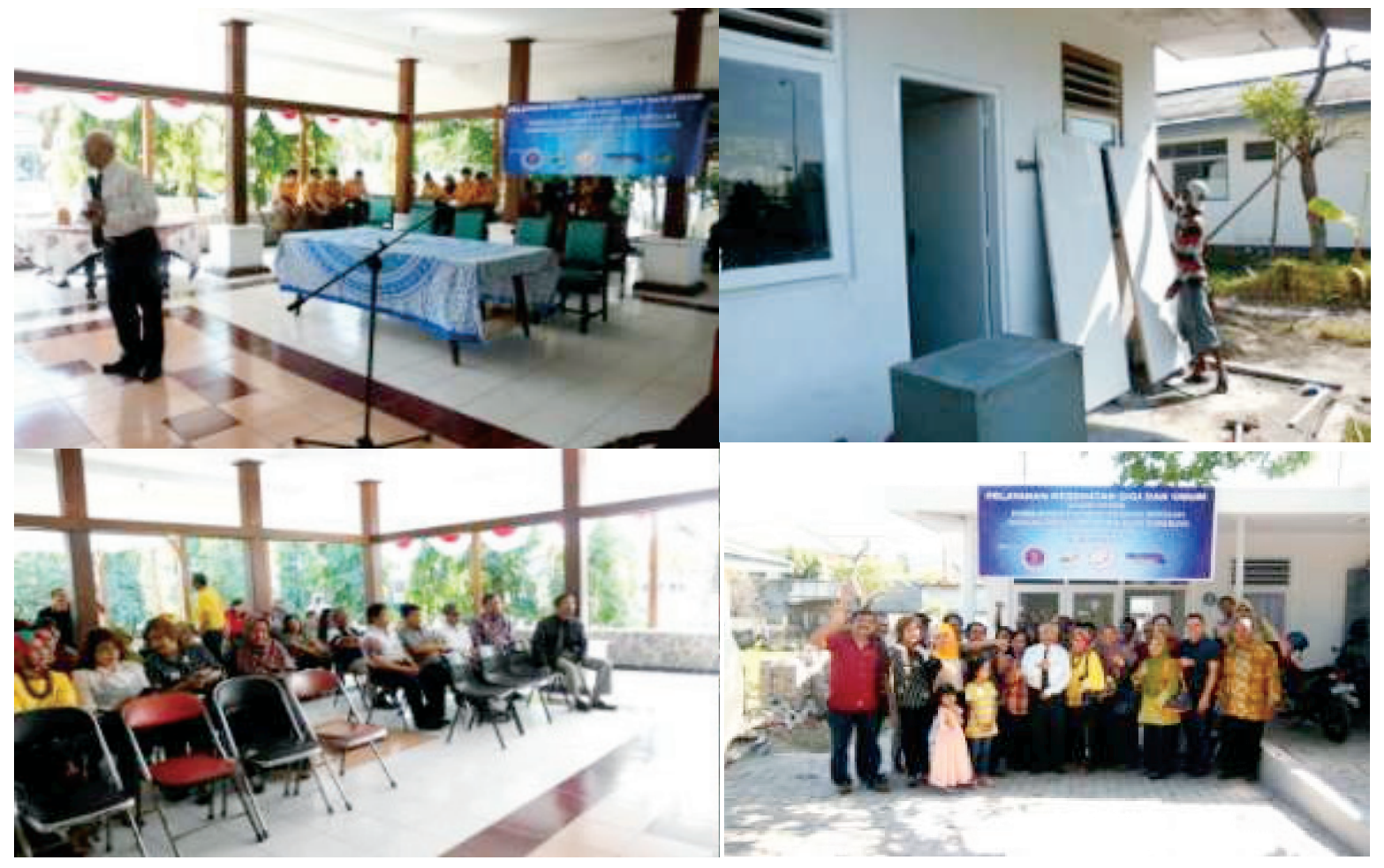

Gambar 5. Peresmian renovasi UKS oleh Prof dr HR Soedarso Djojonegoro, AIF pada tanggal 29 Agustus 2015.

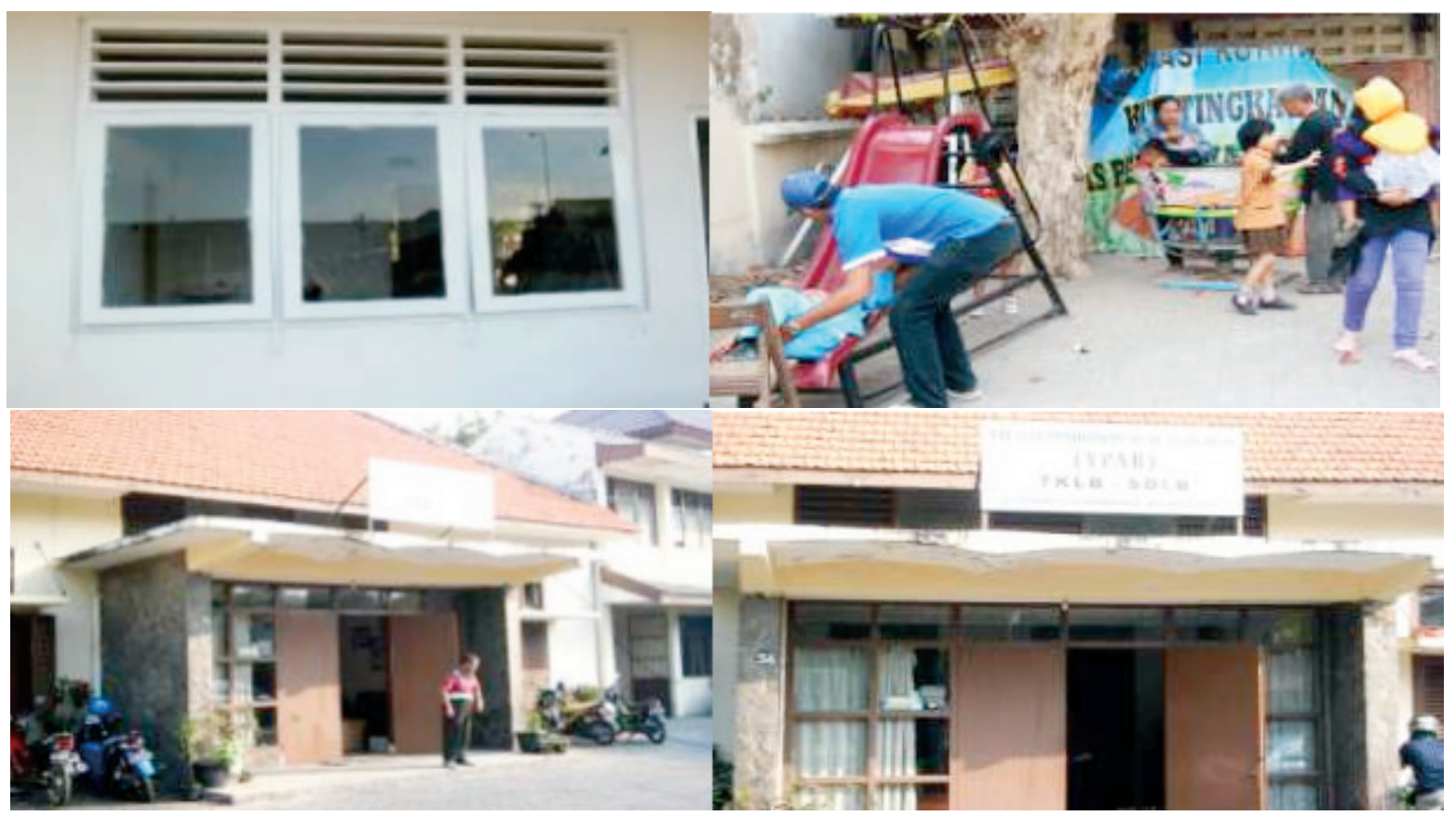

Gambar 6 Suasana asrama dan tempat bermain YPAB yang bersih dan sehat. 
Tabel 1. Jadwal Pelaksanaan Iptek Bagi Masyarakat Layanan Kesehatan Bagi Siswa Tuna Netra

\begin{tabular}{clcl}
\hline No & \multicolumn{1}{c}{ Kegiatan } & Jadwal kegiatan & \multicolumn{1}{c}{ Pelaksana dan nara sumber } \\
\hline 1 & $\begin{array}{l}\text { Renovasi gedung UKS di YPAB } \\
\text { Gebang Putih }\end{array}$ & 24 Juli 2015 & Dr Pratiwi Soesilawati, drg., M.Kes \\
2 & $\begin{array}{l}\text { Pelayanan kesehatan umum, } \\
\text { pemeriksaan lab darah, penyuluhan DHE dan } \\
\text { screening kesehatan gigi di YPAB Tegal Sari }\end{array}$ & 22 Agustus 2015 & $\begin{array}{l}\text { Dr Pratiwi Soesilawati, drg., M.Kes } \\
\text { M. Kresna, dr }\end{array}$ \\
3 & $\begin{array}{l}\text { Pelayanan kesehatan umum, mata } \\
\text { dan gigi di YPAB Gebang Putih }\end{array}$ & 29 Agustus 2015 & $\begin{array}{l}\text { Dr Pratiwi Soesilawati, drg., M.Kes } \\
\text { Menyuluhan dan lomba kebersihan }\end{array}$ \\
& 15 Agustus 2015 & Dr Pratiwi Soesilawati, drg., M.Kes \\
\hline
\end{tabular}

\section{Aspek Kewirausahaan}

\section{Peningkatan soft skill untuk wirausaha jamur tiram}

Permasalahan berikutnya adalah memberikan bekal soft skill bagi siswa YPAB agar mereka mampu mandiri secara ekonomi. Dengan mempertimbangkan adanya lahan tidur di sekitar asrama, dan pemilihan wirausaha yang sesuai dengan keterbatasan siswa, maka kami memilih memberikan pelatihan wirausaha jamur tiram dengan pertimbangan pengelolaan wirausaha ini dapat dikendalikan dengan mengandalkan indera peraba. Kendala yang ditemui dari pelatihan ini adalah belum tersedia tenaga pelatih pembiakan jamur tiram. Maka kami melakukan kerjasama dengan Fakultas Pertanian Universitas Pembangunan nasional Surabaya untuk memeperoleh pendampingan wirausaha jamur tiram. Kegiatan yang telah dilakukan adalah:

\section{Pembangunan rumah jamur}

Pembangunan telah dilakukan pada awal bulan April 2015. Dilakukan pada lahan tidur di halaman YPAB pada ruangan berukuran $3 \mathrm{~m}$ x $9 \mathrm{~m}$. Sekeliling ruang ini ditutup dengan anyaman bambo tebal untuk mempertahankan kelembababn, dilapisi dengan paranet hitam untuk menyaring sinar matahari yang masuk. Dalam rumah jamur ini didirikan dua jalur rak penyimpanan log media jamur yang mampu menampung 4.000 buah log media. Pada tahap awal telah disiapkan 1.000 log media. Pada tanggal 30 April, rumah jamur telah siap untuk diisi log media. Hingga saat ini telah dilakukan panen jamur tiram yang lebih dari cukup digunakan sebagai bahan konsumsi sehari-hari bagi siswa YPAB. Hasil panen jamur tiram yang dimanfaatkan untuk konsumsi siswa di asrama YPAB mampu mengurangi biaya konsumsi di yayasan ini sebesar $24 \%$ dari total pembelanjaan konsumsi di asrama ini.

\section{Pelatihan wirausaha jamur tiram}

Pelatihan ini telah dilaksanakan pada tanggal 25 April 2015. Pelatihan diberikan oleh Ir Widi Wurjani, MSi dari
Fakultas Pertanian UPN Veteran Surabaya. Pelatihan yang diberikan meliputi materi pembangunan rumah jamur, syarat dan kondisi rumah jamur yang ideal, pengaturan suhu dan penyiraman, pengaturan dan pembuatan log media, serta cara memanen jamur tiram. Pelatihan ini diikuti oleh siswa YPAB, guru, karyawan dan orang tua siswa. Keikut sertaan orang tua siswa ini diharapkan agar orang tua mampu mendampingi putra putrinya jika suatu saat nanti mereka memulai berwirausaha.

\section{Pelatihan Keterampilan Pengolahan Jamur Tiram}

Bila wirausaha ini telah menghasilkan jamur tiram, permasalahan berikutnya yang harus dipecahkan adalah pengolahan hasil panen jamur tiram dan pemasaran hasil panen serta produk olahan jamur tiram. Pengolahan hasil panen berupa pengawetan dan merubah hasil panen menjadi produk olahan dilakukan melalui kerjasama dengan Fakultas Pertanian Universitas Pembangunana nasional Veteran Surabaya. Pelatihan telah dilaksanakan pada tanggal 19 September 2015 meliputi adalah pembuatan nugget jamur, sate jamur dan keripik jamur tiram rendah kolesterol. Selanjutnya pemasaran hasil panen dan produk olahan dilakukan di pasar tradisional, swalayan dan pemasaran melalui bisnis online. Pelaksanaan pelatihan pada akhir masa pelaksanaan Iptek bagi Masyarakat ini bertujuan untuk memberi bekal siswa untuk menjaga kesinambungan proyek rumah jamur tiram agar produksi jamur bisa tertampung dan meningkatkan derajat ekonomi siswa.

\section{Pelatihan menejemen pemasaran hasil jamur tiram}

Pelatihan ini meliputi menejemen keuangan sederhana untuk menjaga kesinambungan rumah jamur melalui pelatihan cara penghitungan modal dan laba dan cara menghitung laba yang harus disisihkan untuk pemeliharaan usaha serta pengelolaan laba yang dapat dinikmati untuk kesejahteraan siswa. 


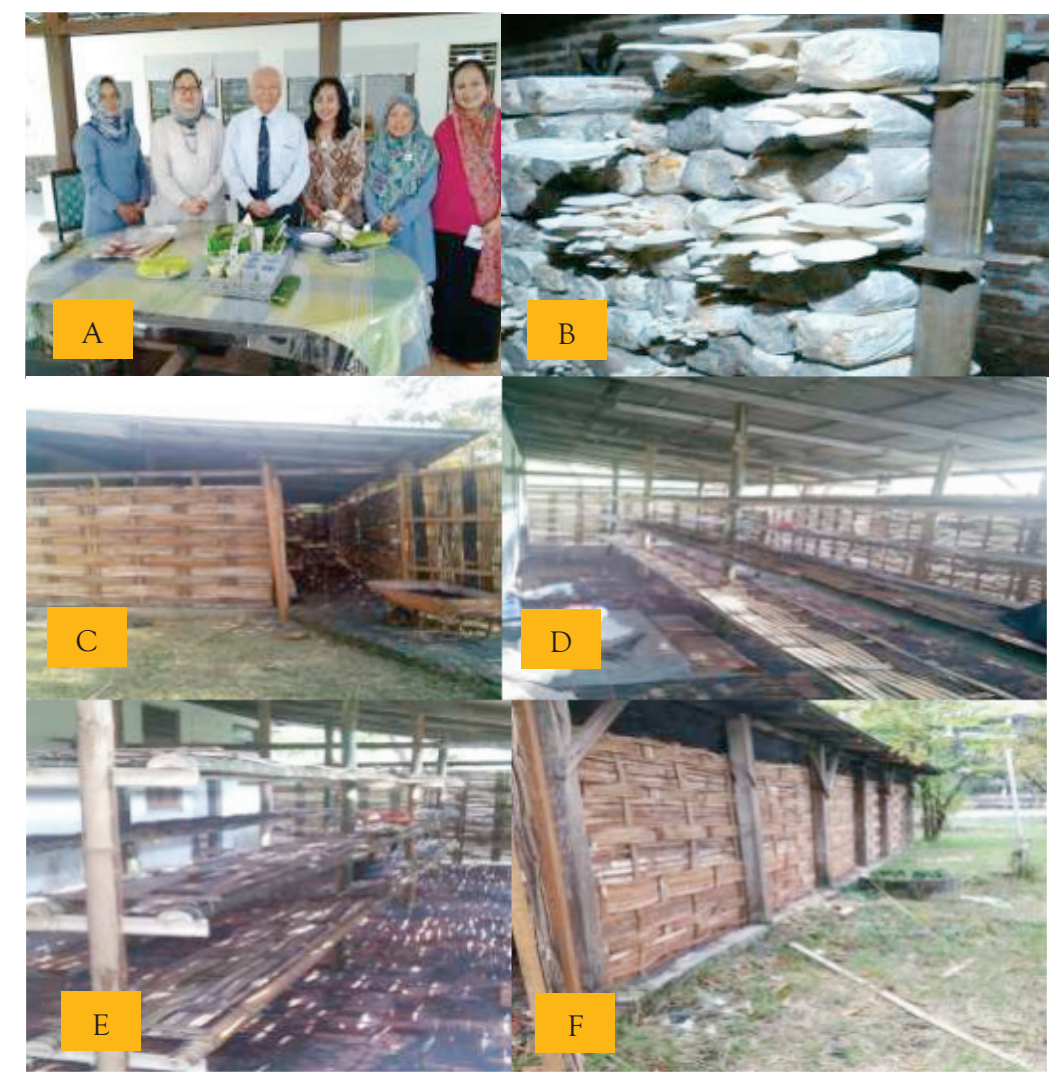

Gambar 7. Pembangunan rumah jamur A. Peresmian pembangunan rumah jamur tiram oleh ketua yayasan YPAB Prof Dr H R Soedarso Djojonegoro, AIF didampingi pengurus yayasan dan guru YPAB. B. Panen pertama jamur tiram tanggal 6 Juni 2015. C. Tampak depan rumah jamur. D,E: tampak dalam rumah jamur. F. Tampak samping rumah jamur.
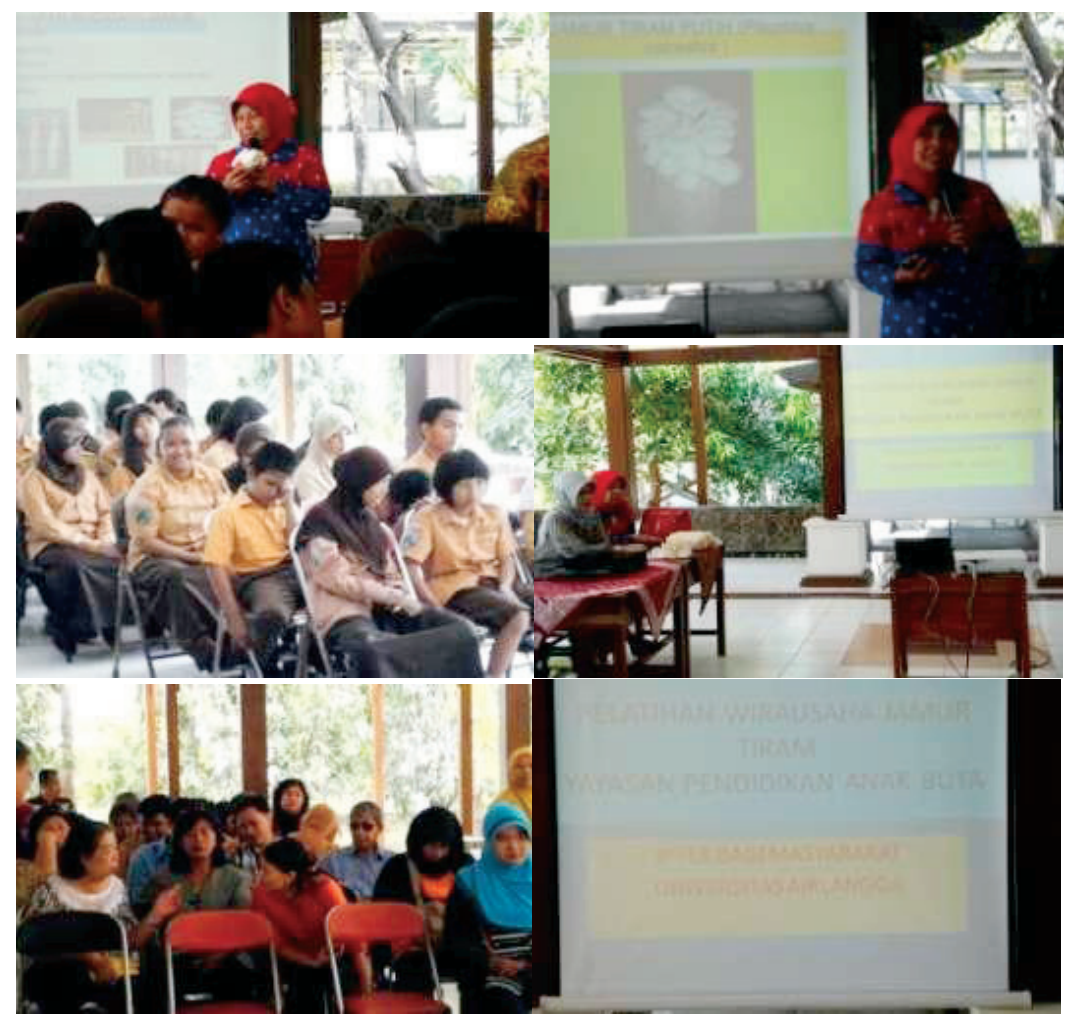

Gambar 8 Suasana pelatihan budidaya jamur tiram oleh Ir Widi Wuryani, MS. Pelatihan ditekankan pada penggunaan bahasa verbal untuk memudahkan siswa tuna netra memahami materi pelatihan. 


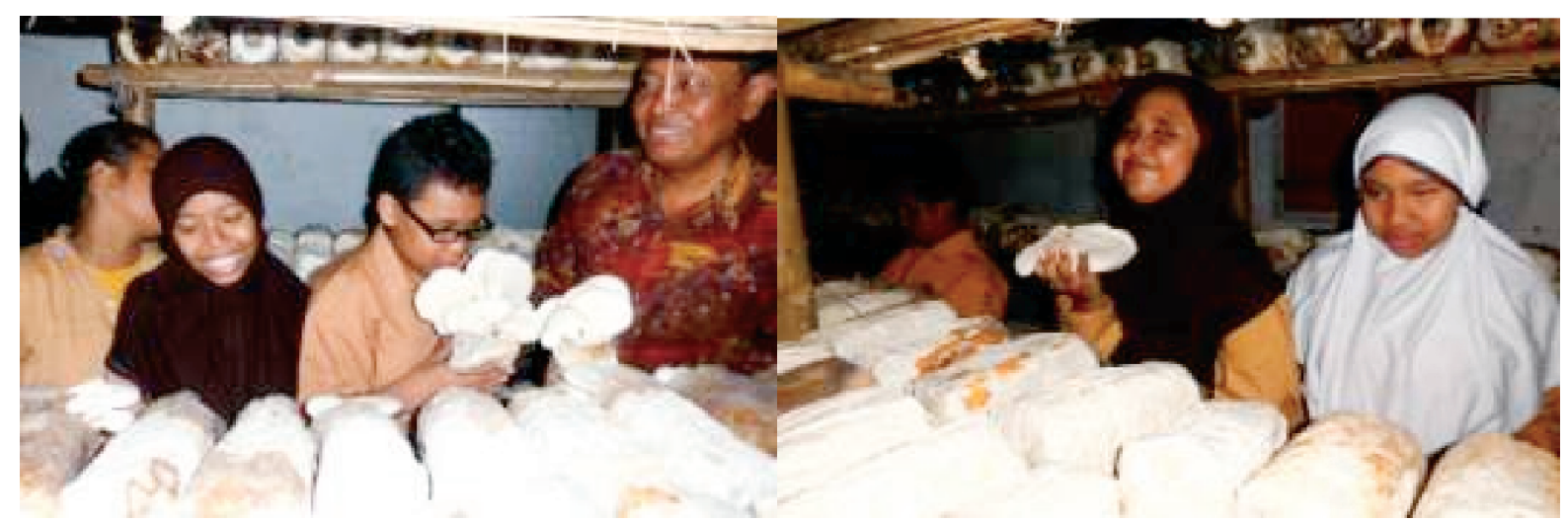

Gambar 9. Guru YPAB terlibat aktif pada proses pemeliharaan jamur tiram melaui pengenalan bentuk dan bau dari jamur tiram.

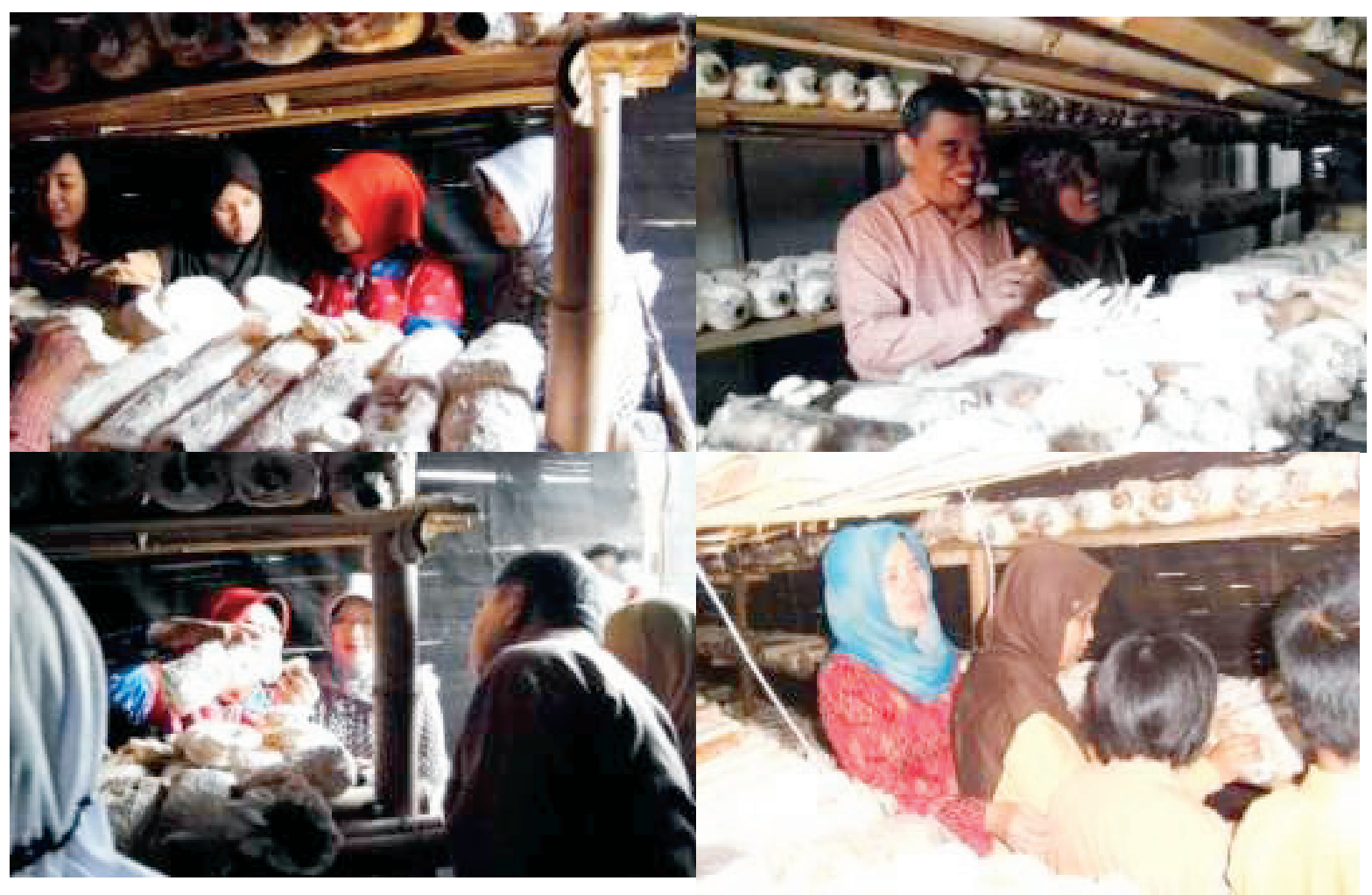

Gambar 10. Orang tua siswa turut serta dalam pelatihan wirausaha jamur tiram.

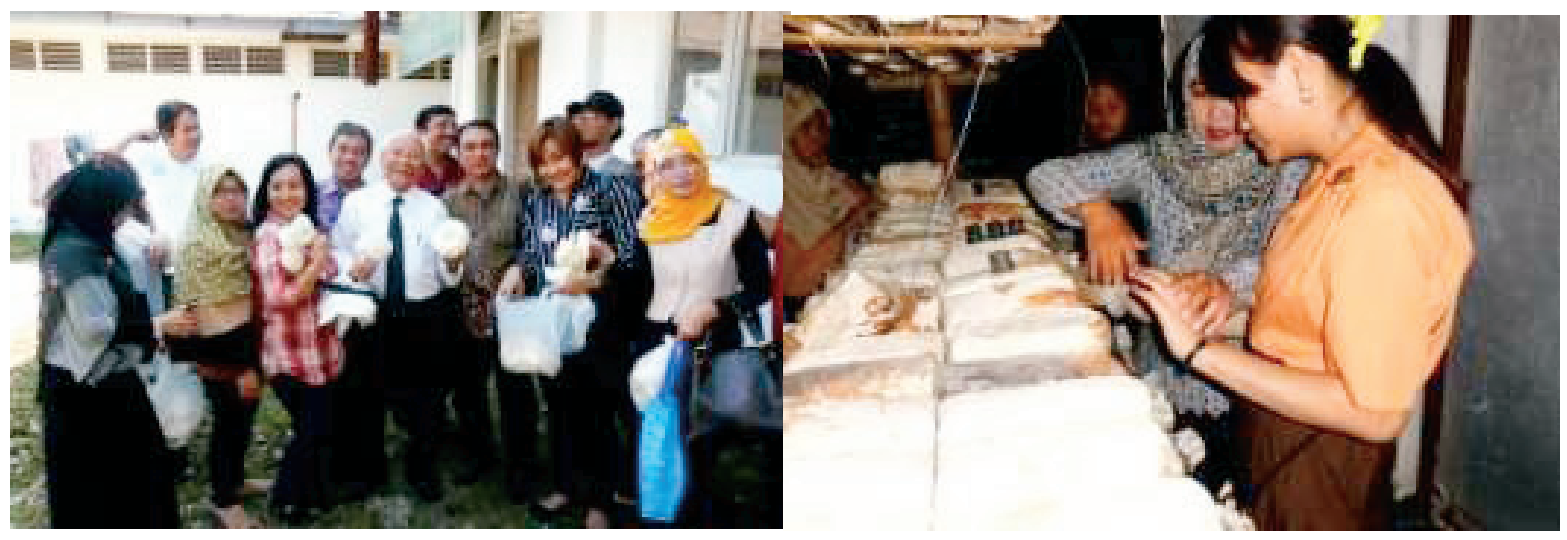

Gambar 11. Budidaya jamur tiram telah menjadi ikon wirausaha YPAB dan dikunjungi oleh berbagai komunitas 
Pratiwi Soesilawati dan R. Darmawan Setijanto: Layanan Kesehatan dan Peningkatan Keterampilan Wirausaha Jamur Tiram

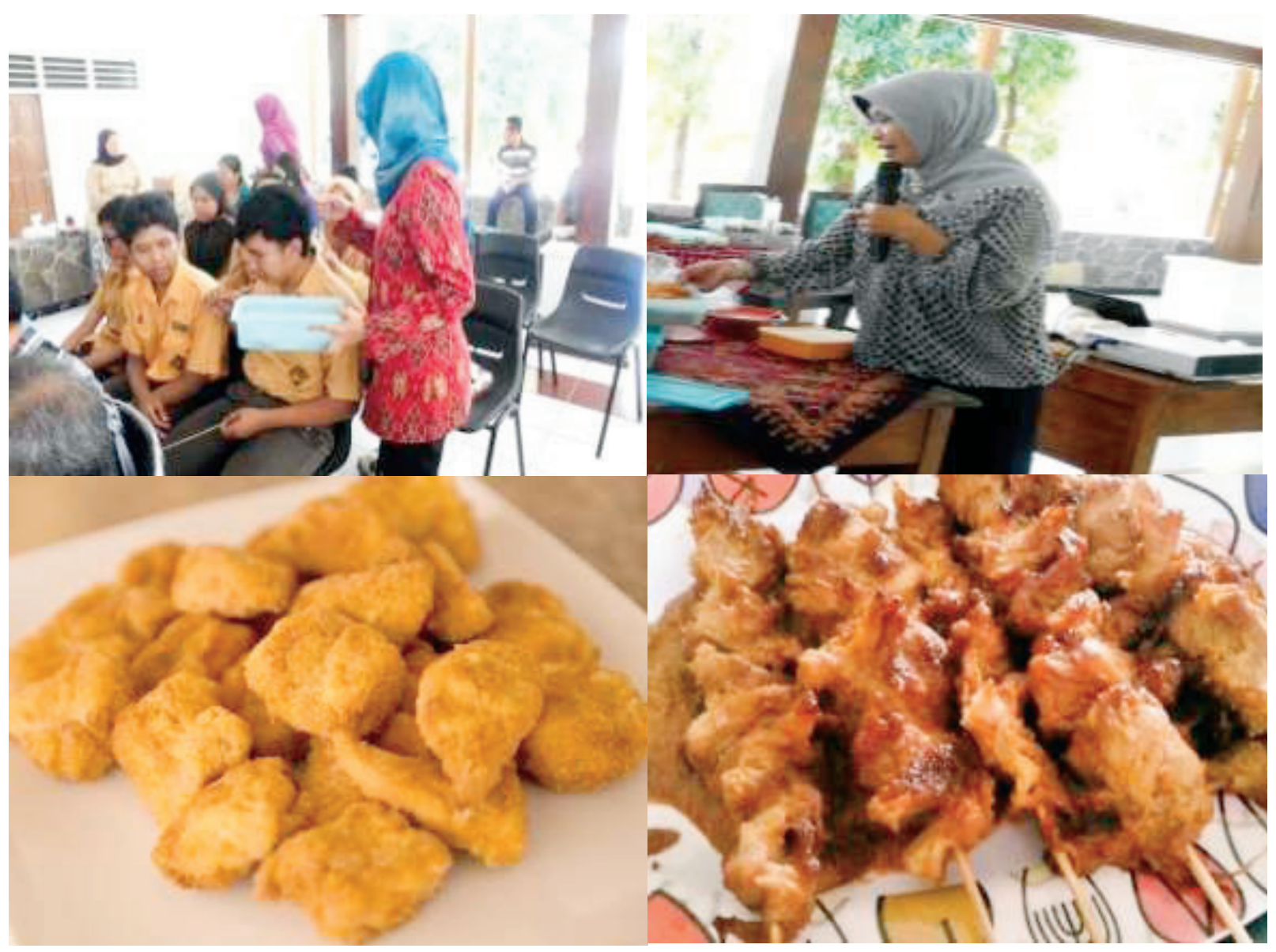

Gambar 12. pelatihan ketrampilan pengolahan jamur tiram menjadi nugget jamur tiram dan sate jamur tiram.

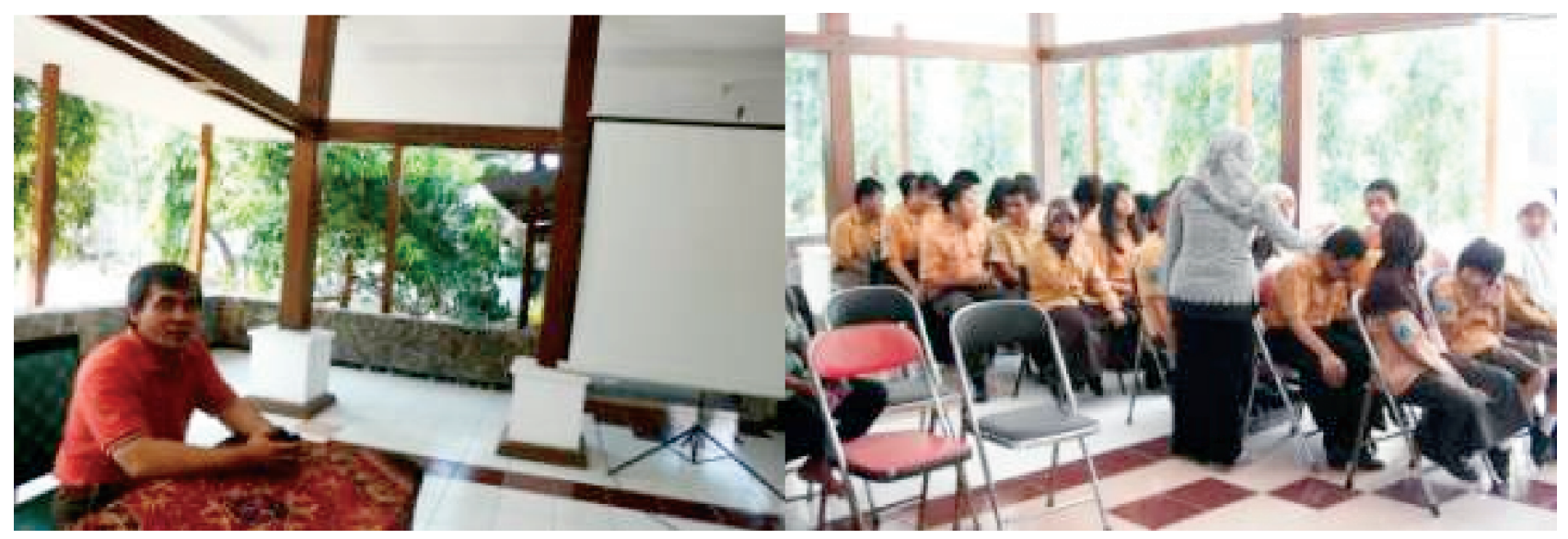

Gambar 13. Pelatihan menejemen pemasaran hasil jamur tiram.

Tabel 2. Pelaksanaan Iptek Bagi Masyarakat Wirausaha Jamur Tiram Bagi Siswa Tuna Netra

\begin{tabular}{clll}
\hline No & \multicolumn{1}{c}{ Kegiatan } & \multicolumn{1}{c}{ Jadwal kegiatan } & \multicolumn{1}{c}{ Pelaksana dan nara sumber } \\
\hline 1 & Pembangunan rumah jamur tiram & 1 April 2015 & $\begin{array}{l}\text { Pembangunan rumah jamur di lahan } \\
\text { tidur YPAB Gebang Putih }\end{array}$ \\
2 & Pelatihan wirausaha jamur tiram & 25 April 2015 & Ir Widi Wurjani, MSi \\
4 & Pelatihan pengolahan jamur tiram & 19 September 2015 & Ir Gunarti, MM \\
5 & Pelatihan menejemen pemasaran hasil jamur tiram & 10 Oktober 2015 & Gunawan Wibisono, SE \\
\hline
\end{tabular}




\section{SIMPULAN}

Layanan kesehatan gigi, umum dan mata bagi siswa, guru dan karyawan di lingkungan YPAB sangat berguna untuk meningkatkan derajat kesehatan siswa, guru dan karyawan. Pembangunan UKS di lingkungan YPAB sangat berguna sebagai sarana penunjang kesehatan siswa. Wirausaha jamur tiram dapat dilaksanakan oleh siswa tuna netra dengan mempertimbangkan keterbatasan mereka. Dari sudut pandang pengurus yayasan YPAB, Pemilihan jenis wirausaha ini dipandang tepat karena hasil wirausaha ini sangat bermanfaat untuk mencukupi kebutuhan protein siswa yang tinggal di asrama. Hasil panen jamur tiram yang dimanfaatkan untuk konsumsi siswa di asrama YPAB mampu mengurangi biaya konsumsi di yayasan ini sebesar $24 \%$ dari total pembelanjaan konsumsi di asrama ini. Dari sudut pandang siswa, terbentuk siswa YPAB yang mandiri secara ekonomi melalui pelatihan wirausaha jamur tiram, Peningkatan keterampilan siswa YPAB dalam bidang pengawetan dan pengolahan hasil panen jamur tiram dan Peningkatan pendapatan siswa melalui pelatihan pemasaran hasil panen dan produk olahan jamur tiram.

\section{Saran}

Pelatihan wirausaha ini disarankan oleh pihak yayasan untuk mengikut sertakan alumni. YPAB yang saat ini telah lulus SMALB dan tidak melanjutkan ke perguruan tinggi. Dibutuhkan peralatan pembuatan log media untuk membimbing siswa menjadi enterprener yang mampu berusaha secara mandiri.

\section{DAFTAR PUSTAKA}

Alma, Buchari. (2010). Kewirausahaan (edisi revisi). Bandung: CV Alfabeta.

Eka Aprilianty(2012)." Pengaruh Kepribadian Wirausaha, Pengetahuan Kewirausahaan, Dan Lingkungan Terhadap Minat Berwirausaha Siswa SMK “. Jurnal Pendidikan Vokasi, Vol 2, Nomor 3, November 2012

Ikaputera Waspada, Sukses Wirausaha Sukes Profit http:// jurnal.upi.edu/file/Ika_P.pdf

Kementrian Pendidikan Nasional (2010). Pengembangan Pendidikan Kewirausahaan. Bahan Pelatihan: Penguatan Metodologi Pembelajaran Berdasarkan Nilai-nilai Budaya untuk Membentuk Daya Saing dan Karakter Bangsa. Jakarta: Badan Penelitian dan Pengembangan Pusat Kurikulum,Kemendiknas.

Saiman, Leonardus. (2009). Kewirausahaan. Teori, Praktik, dan Kasus-kasus. Jakarta. Salemba Empat.

Sony Heru Priyanto (2009). "Mengembangkan Pendidikan Kewirausahaan di Masyarakat", Andragogia Jurnal PNFI / Volume 1 / No 1 - Nopember 2009

Soegoto, E. S. 2009. Entrepreneurship; Menjadi Pebisnis Ulung. Jakarta: Penerbit PT. Elex Media Komputindo.

Kemendikbud. 2012. Panduan Program Mahasiswa Wirausaha. Direktorat Pembelajaran dan Kemahasiswaan, Direktorat Jenderal Pendidikan Tinggi.

Tejo Nurseto (2004)." Strategi Menumbuhkan Wirausaha Kecil Menengah Yang Tangguh". Jurnal Ekonomi \& Pendidikan, Volume 1, Nomor 1, Februari www.jpnn. com/read/ 2011/03/23/87627/ 